Archives of Agriculture and Environmental Science

\title{
Evaluation of bloom dynamics and seasonal abundance of cyanobacteria in eutrophic fish culture ponds at three different regions of Bangladesh
}

\author{
Md. Ayenuddin Haque, Md. Abu Sayed Jewel* (D), Priyangka Das, Mst. Samsad Khatun, Jakia \\ Hasan and Sharmin Jahan
}

Department of Fisheries, University of Rajshahi, Rajshahi, BANGLADESH

*Corresponding author's E-mail: jewelru75@yahoo.com

\section{ARTICLE HISTORY}

Received: 30 January 2019

Revised received: 26 February 2019

Accepted: 01 March 2019

\section{Keywords}

Bloom dynamics

Culture ponds

Cyanobacteria

Eutrophic fish culture

Seasonal abundance

\begin{abstract}
Seasonal cycle and bloom dynamics of cyanobacteria in relation to environmental parameters were studied in three areas- Godagari Upazila under Rajshahi district (GD ponds), Bogra city (BG ponds) and Singra upazila under Natore district (SG ponds) from September 2014 to August 2015. Standard methods were followed to analyze the water quality, sediment parameters and cyanobacterial cell density. Except temperature, mean values of all water quality parameters were found significantly different $(P<0.05)$ among the three study sites. 7 genera of cyanobacteria were identified whereas the highest density was recorded during September in all the studied ponds in order of BG ponds $\left(130.36 \times 10^{6}\right.$ cells $\left./ \mathrm{l}\right)>\mathrm{SG}$ ponds $\left(84.93 \times 10^{6}\right.$ cells $\left./ \mathrm{I}\right)>\mathrm{GD}$ ponds $\left(58.74 \times 10^{6}\right.$ cells/l). Gradual decrease in cell density was observed from November to January, whereas the lowest density $\left(12.25 \times 10^{6}\right.$ cells/l) was recorded at BG ponds in December, 2014. Higher values of soil organic matter, total nitrogen and $\mathrm{pH}$ were found to play significant role in determining higher cyanobacterial cell density at BG ponds compared to SG and GB ponds. The dominant species recorded in all the three studied regions was Microcystis sp.
\end{abstract}

(C)2019 Agriculture and Environmental Science Academy

Citation of this article: Haque, M.A., Jewel, M.A.S., Das, P., Khatun, M.S., Hasan, J. and Jahan, S. (2019). Evaluation of bloom dynamics and seasonal abundance of cyanobacteria in eutrophic fish culture ponds at three different regions of Bangladesh. Archives of Agriculture and Environmental Science, 4(1): 27-32, https://dx.doi.org/10.26832/24566632.2019.040104

\section{INTRODUCTION}

Cyanobacteria are photosynthetic microorganisms that subsist in diverse terrestrial and aquatic environments, including fish ponds, throughout the world. When conditions are favorable, cyanobacteria form blooms in ponds (Gikuma-Njuru et al., 2005). Cyanobacteria (blue-green algae) in the genera Anabaena, Aphanizomenon, Microcystis, and Oscillatoria often form extensive and persistent blooms in freshwater aquaculture ponds (Bold and Wyne, 1978). Bloom-forming cyanobacteria are undesirable in aquaculture ponds because: 1) they are a relatively poor base for aquatic food chains; 2) they are poor oxygenators of the water and have undesirable growth habits; 3) some species produce odorous metabolites that impart undesirable flavors to the cultured animal; and 4) some species may produce compounds that are toxic to aquatic animals (Pearl and Tucker, 2007). Toxic cyanobateria are now recognized as a hazard to human and animal welfare and health assessments are being carried out to determine environmental health problems (Skulberg et al., 1984; Carmichael, 1994; 1995). Living in the aquatic environment, fish in a variety of ways come into contact with cyanobacteria and their toxins, which affect their growth, development, histology, reproduction and survival (Palikova et al., 2007; Deng et al., 2010; Svircev et al., 2015). Even mortality of fishes, bad odour from decayed algae and bad odour from cooked fish muscle has been reported in ponds having algal blooms (Jewel et al., 2006; Rahman and Jewel, 2008). It is known that cyanobacteria can produce a number of secondary metabolites and compounds. Among these, microcystin is considered to be one of the most dangerous toxins, as it is known to be a potent hepatotoxin that may cause liver damage in humans, fish, and other organisms, and may promote tumor growth (Dawson, 1998). Microcystin contents in fish may vary according to both their exposure time and bloom duration. Therefore, the degree 
of risk of human exposure to microcystin via consumption of fish may vitally depend on the accumulation of microcystin in fish (Chen et al., 2009).

Cyanobacterial blooms are now a common phenomenon in ponds, lakes and reservoirs in Bangladesh. With gradual increase of aquaculture, specially intensive and semi-intensive aquaculture, fish farmers are experiencing many unexpected problems among which environmental degradation with noxious algal blooms and aquatic toxicity are most alarming. For getting higher fish production fish farmers apply high doses of fertilizers and feeds in their ponds. As a result, the confined waters of the ponds have become eutrophicated due to sedimentation of nutrients from fertilizers and from decomposed organic matters which induce toxic and noxious blooms of cyanobacteria by Microcystis aeruginosa, Anabaena flosaquae, Aphanizomenon flos-aqua (Jewel et al., 2003; Rahman and Jewel, 2008). Changes in environmental condition with increasing temperature of water body, the occurrence of cyanobacterial bloom is increasing day by day. Other factors such as $\mathrm{pH}$ and $\mathrm{DO}$ in particular are also reported to have strong correlations with algal concentration in water column. Apart from that, due to the increase in urbanization and industrialization nutrient input in household ponds become increasing subsequently and the particular algae take the advantage of eutrophic aquaculture situations. Since there are lacks of cyanobacteria research in Bangladesh especially in aquaculture industry, this study was conducted to determine the abundance of cyanobacterial biomass in aquaculture system in selected three regions of Bangladesh. This study also aims to identify the relationship between environmental factors (e.g. temperature, $\mathrm{DO}, \mathrm{pH}$ and nutrients) with relative abundance of cyanobacteria in fish aquaculture ponds by assessing the relationships in the study locations. This study is important for public health risk protection to ensure safe fish supply to be delivered to consumers.

\section{MATERIALS AND METHODS}

\section{Site selection}

The study was conducted from September 2014 to August 2015 in 9 fish culture ponds at three different locations of Rajshahi Division (three ponds from Godagari Upazila under Rajshahi district (GD ponds), three ponds from Shingra Upazila under Natore district (SG ponds) and three ponds from Bogra Sadar Upazila under Bogra district (BG) (Figure 1). The Global Positioning System (GPS) coordinates of sampling ponds are as shown in Table 1. All of the chosen ponds comprised of earth ponds and used for fish culture.

\section{Monitoring of physico-chemical parameters}

Monitoring of the physico-chemical parameters was based on the procedure of APHA (1998). Surface water samples were collected once in a month between 10:00 and 11:00 h for analysis of various physico-chemical parameters using dark bottles. The water samples were chilled in ice and transferred to the laboratory at $4^{\circ} \mathrm{C}$. Surface water temperature and transparency were measured using a Celsius thermometer and a black and white standard colour coded Secchi disc. Water pH was measured using an electronic $\mathrm{pH}$ meter (Jenwary, 3020). Nitrate -nitrogen $\left(\mathrm{NO}_{3}-\mathrm{N}\right)$, phosphate-phosphorus $\left(\mathrm{PO}_{4}-\mathrm{P}\right)$ concentrations were measured using the Hach Kit (DR/2010, a directreading spectrophotometer) with high range chemicals (Nitra Ver. 5 Nitrate Reagent Powder Pillows for $25 \mathrm{ml}$ sample for $\mathrm{NO}_{3}$ -N and Phos. Ver. 3 Phosphate Reagent Powder Pillows for 25 $\mathrm{ml}$ sample for $\mathrm{PO}_{4}-\mathrm{P}$ analysis). Dissolved oxygen (DO) and total alkalinity were measured by using a portable aquaculture kit (Model FF2, HACH, USA). Biological Oxygen Demand (BOD) was measured by using Hach BOD Trak meter (model No. 205) through measuring initial and final BOD after incubation in dark for five days.

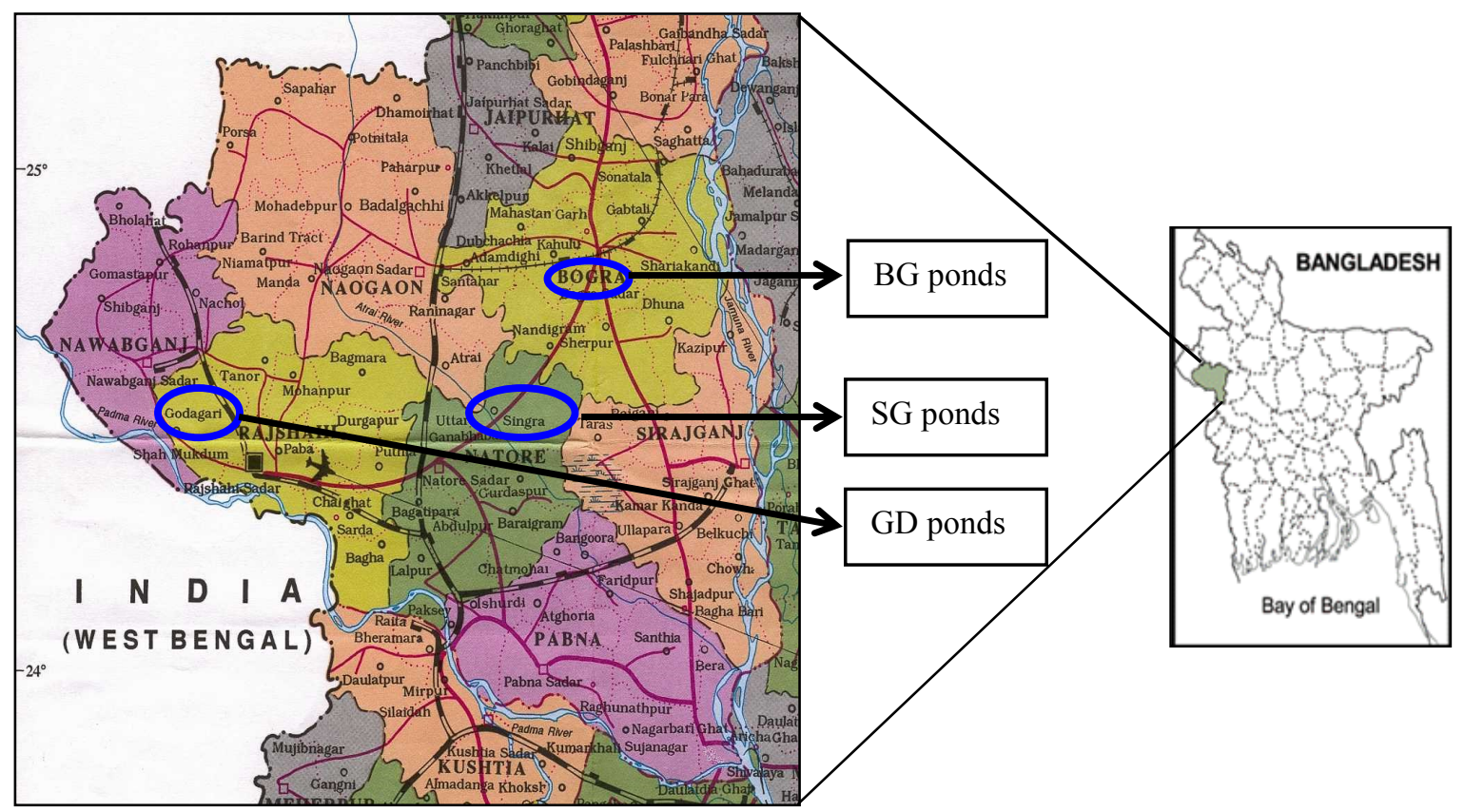

Figure 1. Blue circles are indicating the study area within Rajshahi Division. 
Table 1. Global Positioning System (GPS) coordinates of sampling ponds.

\begin{tabular}{lcl}
\hline Locations & Ponds & GPS coordinate \\
\hline \multirow{2}{*}{ Godagari Upazila under Rajshahi district } & 1 & $24^{\circ} 28^{\prime} 23.46^{\prime \prime} \mathrm{N}, 88^{\circ} 26^{\prime} 25.40^{\prime \prime} \mathrm{E}$ \\
& 2 & $24^{\circ} 28^{\prime} 03.45^{\prime \prime} \mathrm{N}, 88^{\circ} 25^{\prime} 38.50^{\prime \prime} \mathrm{E}$ \\
Shingra Upazila under Natore district & 3 & $24^{\circ} 29^{\prime} 14.14^{\prime \prime} \mathrm{N}, 88^{\circ} 27^{\prime} 15.23^{\prime \prime} \mathrm{E}$ \\
& 4 & $24^{\circ} 28^{\prime} 26.85^{\prime \prime} \mathrm{N}, 89^{\circ} 08^{\prime} 00.94^{\prime \prime} \mathrm{E}$ \\
Bogra Sadar Upazila under Bogra district & 5 & $24^{\circ} 28^{\prime} 25.83^{\prime \prime} \mathrm{N}, 89^{\circ} 07^{\prime} 55.27^{\prime \prime} \mathrm{E}$ \\
& 6 & $24^{\circ} 28^{\prime} 28.93^{\prime \prime} \mathrm{N}, 89^{\circ} 07^{\prime} 56.38^{\prime \prime} \mathrm{E}$ \\
& 7 & $24^{\circ} 50^{\prime} 58.99^{\prime \prime} \mathrm{N}, 89^{\circ} 21^{\prime} 59.93^{\prime \prime} \mathrm{E}$ \\
\hline
\end{tabular}

Soil quality monitoring

Soil quality in terms of organic matter (OM), total nitrogen (TN) and $\mathrm{pH}$ of the selected ponds were monitored at the start (September 2014) and at the end of the study period (August 2015). Soil samples were tested in the laboratory of Soil Resource Development Institute (SRDI), Shyampur, Rajshahi. Organic matter and total nitrogen were calculated by the following formula:

Organic Matter (\%) = Organic Carbon (\%) $\times 1.724$

Total Nitrogen (\%) = Organic Carbon (\%) $\div 12$

\section{Cyanobacterial study}

Water samples were collected using phytoplankton net $(25 \mu \mathrm{m}$ mesh size) and fixed in $5 \%$ formalin on site. Identification of the cyanobacterial species were conducted under a phase contrast light microscope (Olympus CX21, Tokyo, Japan) with bright field and phase contrast illumination (Anagnostidis and Komarek 1985; Skulberg et al., 1993). Quantitative estimation of cyanobacteria was done on Sedgewick-Rafter counting chamber (S-R cell) by following the formula given by Stirling (1985), $N=$ $\left(A^{*} 1000^{*} C\right) / N^{*} F^{*} L$, where, $N$ is the number cyanobacterial cells or unit per liter of original water, $A$ is the total number of plankton counted, $C$ is the volume of final concentrate of the sample in $\mathrm{ml}, \mathrm{V}$ is the volume of a field, $F$ is the number of the field counted, $L$ is the volume of original water in liter.

\section{Statistical analysis}

For the statistical analysis of data collected, one-way analysis of variance (ANOVA) was performed using the SPSS (Statistical Package for Social Science, evaluation version-20.0, IBM
Corporation, Armonk, NY, USA). The mean values were also compared to see the significant difference through DMRT (Duncan Multiple Range Test) at 5\% level of significance (Gomez and Gomez, 1984). The percentages and ratio data were analyzed using arcsine transformed data.

\section{RESULTS AND DISCUSSION}

\section{Water quality parameters}

Variations in the mean values of water quality parameters during the study period are shown in Table 2. Mean water quality parameters in BG ponds were more or less within the suitable range as compared to other ponds (SG and GD). Present findings agreed with Boyd (2012), who reported the acceptable water temperature $25-32^{\circ} \mathrm{C}$, secchi depth due to phytoplankton turbidity $30-45 \mathrm{~cm}, \mathrm{pH} 6-9$, and alkalinity above $20 \mathrm{mg} / \mathrm{l}$ for fish production. Mean water transparency of GD ponds were significantly $(P<0.05)$ lower than BG and SG ponds. The lower value of transparency in GD ponds might be related to the high clay turbidity at that region (a red-soil zone) and might be not for plankton density. In the present study, significantly $(P<0.05)$ lower $\mathrm{pH}$ value was found at GD ponds which is similar to the findings of Hossain et al. (2010) who also recorded lower $\mathrm{pH}$ (acidic condition) value in rice fish culture system at Barind area of Rajshahi. Dissolved oxygen, BOD, total alkalinity and nutrients $\left(\mathrm{NO}_{3}-\mathrm{N}\right.$ and $\left.\mathrm{PO}_{4}-\mathrm{P}\right)$ concentrations were relatively high in $\mathrm{BG}$ and $\mathrm{SG}$ ponds compared to $\mathrm{GD}$ ponds. Hossain and Bhuiyan (2007) also found lower alkalinity, dissolved oxygen and nutrient concentrations in red soil zone (Barind area).

Table 2. Mean variation of different water quality parameters in BG, SG and GD fish ponds.

\begin{tabular}{|c|c|c|c|c|c|}
\hline \multirow{2}{*}{ Parameters } & \multicolumn{3}{|c|}{ Sampling sites } & \multirow{2}{*}{$p$-value } & \multirow{2}{*}{ Level of significance } \\
\hline & BG ponds & SG ponds & GD ponds & & \\
\hline Temperature $\left({ }^{\circ} \mathrm{C}\right)$ & $27.71 \pm 1.84^{a}$ & $27.84 \pm 1.82^{a}$ & $28.43 \pm 1.99^{a}$ & 0.959 & NS \\
\hline Transperancy $(\mathrm{cm})$ & $34.06 \pm 1.84^{a}$ & $38.06 \pm 1.97^{a}$ & $23.69 \pm 1.27^{b}$ & 0.000 & $*$ \\
\hline $\mathrm{pH}$ & $7.85 \pm 0.14^{a}$ & $7.80 \pm 0.13^{\mathrm{a}}$ & $6.10 \pm 0.14^{b}$ & 0.000 & * \\
\hline $\mathrm{DO}(\mathrm{mg} / \mathrm{l})$ & $4.50 \pm .14^{\mathrm{a}}$ & $4.32 \pm 0.15^{\mathrm{a}}$ & $3.81 \pm 0.17^{b}$ & 0.010 & * \\
\hline $\mathrm{BOD}_{5}(\mathrm{mg} / \mathrm{l})$ & $2.37 \pm 0.25^{\mathrm{a}}$ & $2.05 \pm 0.14^{\mathrm{ab}}$ & $1.74 \pm 0.18^{b}$ & 0.041 & * \\
\hline $\mathrm{NO}_{3}-\mathrm{N}(\mathrm{mg} / \mathrm{l})$ & $1.87 \pm 0.23^{\mathrm{a}}$ & $1.66 \pm 0.21^{a}$ & $1.26 \pm 0.17^{\mathrm{a}}$ & 0.265 & NS \\
\hline $\mathrm{PO}_{4}-\mathrm{P}(\mathrm{mg} / \mathrm{l})$ & $0.64 \pm 0.08^{a}$ & $0.50 \pm 0.07^{a b}$ & $0.38 \pm 0.07^{b}$ & 0.045 & * \\
\hline Total alkalinity (mg/l) & $141.16 \pm 1.11^{\mathrm{a}}$ & $122.27 \pm 1.17^{b}$ & $31.15 \pm 0.68^{c}$ & 0.000 & * \\
\hline
\end{tabular}

*, Significant at $5 \%$ level; NS, Not significant; BG ponds: Bogra ponds, SG ponds: Singra ponds, GD ponds: Godagari ponds. 
Soil quality parameters

Mean variation in soil quality parameters e.g. organic matter (OM \%) pH and total nitrogen (\%) are shown in Table 3. Soil organic matter, total nitrogen content and $\mathrm{pH}$ value was relatively high in BG and SG ponds compared to GD ponds that indicate soil productivity of GD ponds was lower than other two sites. Similarly, lower soil organic matter, total nitrogen content and $\mathrm{pH}$ value were also recorded by Hossain et al. (2010) during their study in Barind area.

Cyanobacterial analysis

The Cyanobacterial cell density varied from $12.25 \times 10^{6}$ to
$130.36 \times 10^{6} \mathrm{cells} / \mathrm{l}$ at BG ponds, $8.46 \times 10^{6}$ to $84.93 \times 10^{6} \mathrm{cells} / \mathrm{l}$ at SG ponds and $5.9 \times 10^{6}$ to $58.75 \times 10^{6}$ cells/l at GD ponds (Figure 2). A total of 17 species of cyanobacteria was identified, namely Microcystis aeruginosa, $M$. wesenbergii, $M$. robusta, $M$. viridis, $M$. natans, M. botrys, Anabaena circinalis, A. microspora, A. curva, Planktothrix agardhii, P. rubescens, P. anagnostidis, Aphanocapsa nageli, Aphanizomenon flos-aquae, Merismopedia nageli, Oscillatoria voucher, O. agardhii. Mean cell density of Cyanobacteria was varied from $22.01 \pm 4.22$ cells/l (GD ponds) to $54.02 \pm 12.20$ cells/l (BGponds). There was a significant difference $(p>0.05)$ in cyanobacteria cell density was found among the three sampling sites (Table 4).

Table 3. Variation in the mean value of soil quality parameters in in BG, SG and GD fish ponds.

\begin{tabular}{llcc}
\hline \multirow{2}{*}{ Soil quality parameters } & \multicolumn{3}{c}{ Sampling sites } \\
\cline { 2 - 4 } & BG ponds & SG ponds & GD ponds \\
\hline Start of the study & & & \\
Organic matter (\%) & $1.25 \pm 0.02^{\mathrm{a}}$ & $1.22 \pm 0.07^{\mathrm{ab}}$ & $1.19 \pm 0.09^{\mathrm{b}}$ \\
Total nitrogen (\%) & $0.11 \pm 0.02^{\mathrm{a}}$ & $0.09 \pm 0.03^{\mathrm{ab}}$ & $0.10 \pm 0.01^{\mathrm{b}}$ \\
pH & $7.02 \pm 0.25^{\mathrm{a}}$ & $7.05 \pm 0.30^{\mathrm{a}}$ & $6.50 \pm 0.25^{\mathrm{a}}$ \\
End of the study & & & \\
Organic matter (\%) & $1.73 \pm 0.04^{\mathrm{a}}$ & $1.57 \pm 0.04^{\mathrm{ab}}$ & $1.47 \pm 0.03^{\mathrm{b}}$ \\
Total nitrogen (\%) & $0.15 \pm 0.01^{\mathrm{a}}$ & $0.10 \pm 0.02^{\mathrm{ab}}$ & $0.11 \pm 0.015^{\mathrm{b}}$ \\
pH & $7.68 \pm 0.09^{\mathrm{a}}$ & $7.60 \pm 0.06^{\mathrm{ab}}$ & $6.95 \pm 0.03^{\mathrm{b}}$ \\
\hline
\end{tabular}

Figures in a row bearing common letter(s) do not differ significantly ( $p<0.05)$; BG ponds: Bogra ponds, SG ponds: Singra ponds, GD ponds: Godagari ponds.

Table 4. Mean variation in cyanobacteria cell density ( $\times 10^{6}$ cells $\left./ 1\right)$ in BG, SG and GD fish ponds.

\begin{tabular}{cccccc}
\hline \multirow{2}{*}{ Parameters } & \multicolumn{3}{c}{ Sampling sites } & \multirow{2}{*}{ p-value } & Level of significance \\
\cline { 2 - 5 } & BG ponds & SG ponds & GD ponds & & \\
\hline Total cyanobacteria & $54.02 \pm 12.20 \mathrm{a}$ & $35.15 \pm 6.97 \mathrm{ab}$ & $22.01 \pm 4.22 \mathrm{~b}$ & 0.038 & $*$ \\
\hline
\end{tabular}

*, Significant at 5\% level; BG ponds: Bogra ponds, SG ponds: Singra ponds, GD ponds: Godagari ponds.
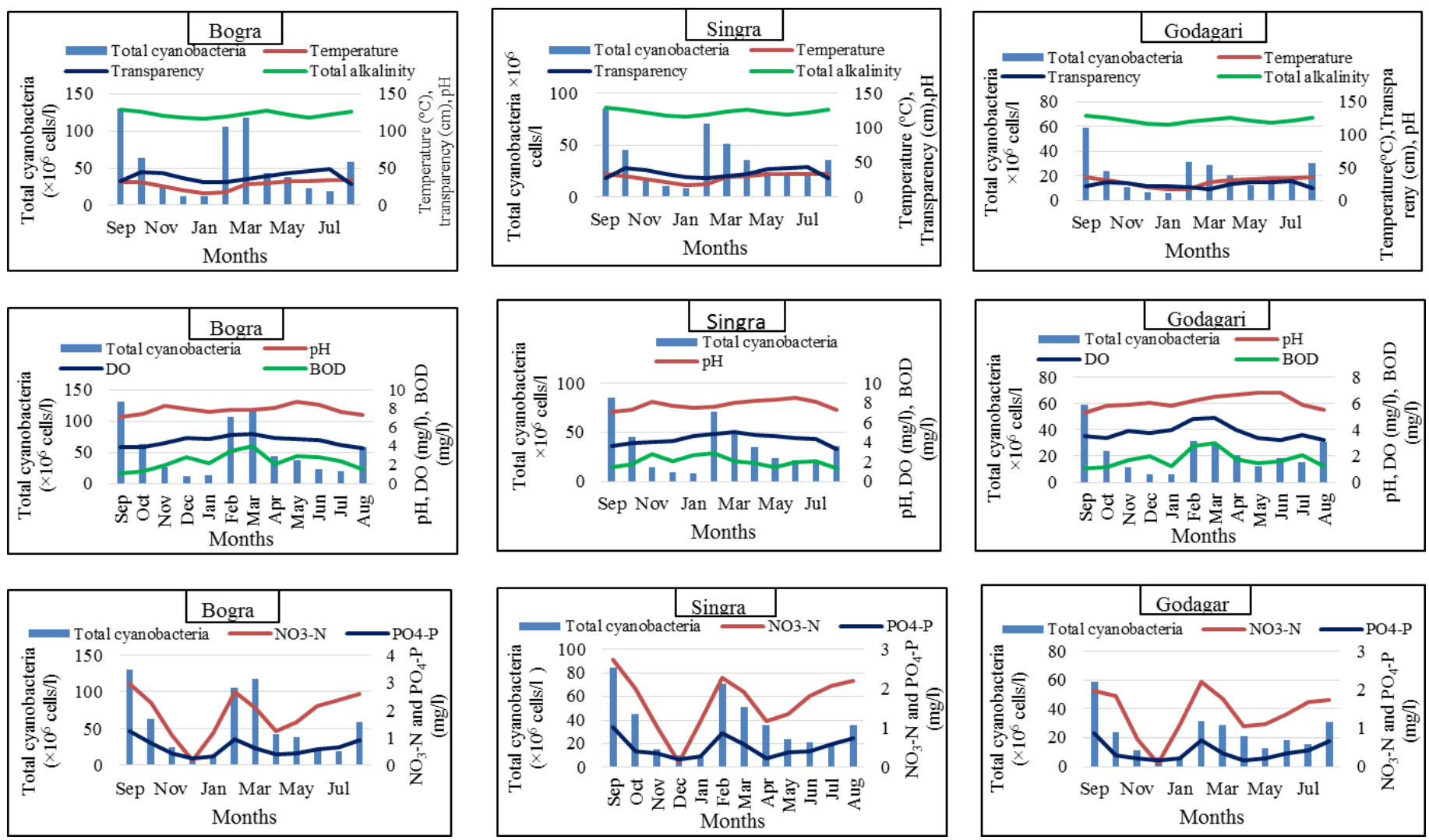

Figure 2. Effect of temperature, transparency, $p \mathrm{H}, \mathrm{DO}, \mathrm{BOD}_{5}, \mathrm{NO}_{3}-\mathrm{N}, \mathrm{PO}_{4}-\mathrm{P}$ and total alkalinity on the total cyanobacterial cell density in $\mathrm{BG}, \mathrm{SG}$ and $\mathrm{GD}$ ponds from September 2014 to August 2015. 
Two peak periods of cyanobacterial bloom were found during the study period. One was in February-March (Spring season) and another was in September (Autumn season) (Figure 2). In spring bloom, rapid multiplication of cyanobacterial cells due to the availability of adequate amounts of nutrients, rising temperature; bright sunlight and $\mathrm{pH}$ were identified as the main factors for bloom formation of cyanobacteria at that time. Similar findings were also reported by Affan et al. (2015) and Li et al. (2018). Rahman and Jewel (2008) also found relatively high cell density of cyanobacteria in fish culture ponds of Rajshahi City Corporation in March (Spring season) and they stated that rising temperature with increasing nutrients concentration were the main factors for high cell density of cyanobacteria at that time. It was also observed that cyanobacterial cell density was the highest in BG ponds $(54.02 \pm 12.20$ cells/l) throughout the study period compared to SG $(35.15 \pm 6.97$ cells/I) and GD $(22.01 \pm 4.22$ cells/I ) ponds. BG ponds were found to receive huge amount of sewage and domestic wastes through drains especially in the rainy season. These nutrient input might trigger higher growth of cyanobacteria in early autumn (September) at sampling ponds of BG $\left(130.08 \times 10^{6}\right.$ cells/l). Jewel et al. (2006) and Rahman and Jewel (2008) also stated that higher nutrient concentrations especially nitrate-nitrogen and phosphate-phosphorus are mainly responsible for higher cell density of cyanobacteria in early autumn in ponds. Cyanobacterial cell density was the lowest at GD ponds and it might be due to lower nutrient concentrations with acidic $\mathrm{pH}$, high turbidity and low alkalinity that were responsible for lower productivity of cyanobacteria in those ponds (Hossain and Bhuiyan, 2007). Similarly higher cyanobacterial growth due to nutrient accumulation during rainy season was found by Rejmánková et al. (2011). Cyanobacterial cell density was found moderate at SG ponds and it might be due to the small amount of nutrient from drainage system and surface-runoff during late rainy season. Cyanobacterial cell density appeared to decrease gradually in the winter months in all the three study sites from November to January might be due to the lower temperature and low nutrient concentrations in those months (Nguyen and Wood, 1979 and Pabst et al., 1980).

\section{Conclusion}

The present findings indicate that higher nutrient concentrations, alkaline $\mathrm{pH}$ with higher alkalinity of water create favorable condition for higher cell abundance of cyanobacteria in BG and SG ponds. However, lower cell density of cyanobacteria in GD ponds (Barind area) indicated low nutrient concentration, high water turbidity, acidic $\mathrm{pH}$ and lower alkalinity. Further study on noxious and harmful cyanobacteria and their toxin should be undertaken to find out the effect of cyanobacterial bloom on fish production in culture ponds.

\section{ACKNOWLEDGEMENT}

The authors are grateful to University Grants Commission (UGC), Bangladesh for providing financial support during accomplishing this experiment.
Open Access: This is an open access article distributed under the terms of the Creative Commons Attribution 4.0 License, which permits unrestricted use, distribution, and reproduction in any medium, provided the original author(s) if the sources are credited.

\section{REFERENCES}

Affan, A., Khomavis, H.S., Al-Harbi, S.M., Haque, M. and Khan, S. (2015). Effect of environmental factors on cyanobacterial abundance and cyanotoxins production in natural and drinking water, Bangladesh. Pakistan Journal of Biological Science, 18(2): 50-8, https://doi.org/10.3923/ pjbs.2015.50.58

Anagnostidis, k. and Komarek, J. (1985). Modern approach to the classification system of Cyanophytes. 1-Introduction. Algological Studies, 38/39: 291-302.

APHA. (1998). Standard methods for the examination of water and wastewater. $20^{\text {th }}$ edn., American Public Health Association, 1015 Fifteenth Street, NW, Washington, DC. pp. 3-103.

Bold, H. C. and Wyne, M. J. (1978). Introduction to the Algae. Prentice-Hall Inc. New Jersey, pp. 706.

Boyd, C.E. (Ed.). (2012). Bottom soils, sediment, and pond aquaculture. Springer Science \& Business Media.

Carmichael, W.W. (1994). Toxins of cyanobacteria, Scientific American, 270(1): 78-86. https://doi.org/10.1038/ scientificamerican0194-78

Carmichael, W.W. (1995). Cyanobacteria toxin, In: G.M. Hallegraff, D.M. Anderson and A.D. Cembella (Eds.), Harmful Marine Microalgae, UNESCO, Paris: 163-175.

Chen, J., Xie, P., Li, L. and Xu, J. (2009). First identification of the hepatotoxic microcystins in the serum of achronically exposed human population together with indication of hepatocellular damage, Toxicological Sciences, 108: 81-89. https://doi.org/10.1093/toxsci/kfp009

Dawson, R.M. (1998). The toxicology of microcystins, Toxicon, 36: $953-962$.

Deng, D., Zhang, S., Li, Y., Meng, X., Li, Y. and Li, X. (2010). Effects of Microcystis aeruginosa on population dynamics and sexual reproduction in two Daphnia species. Journal of Plankton Research, $\quad 32(10)$ : 1385-1392. https://:www.doi.org/10.1093/plankt/fbq069

Gikuma-Njuru, P., Mwirigi, P., Okungu, J., Hecky, R. and Abuodha, J. (2005). Spatial-temporal variability of phytoplankton abundance and species composition in Lake Victoria, Kenya: Implication for water quality management. Proceedings of the $11^{\text {th }}$ World Lake Conference Nairobi, Kenya. 2: 155-159.

Gomez, K.A. and Gomez, A.A. (1984). Statistical Procedures for Agricultural Research. $2^{\text {nd }}$ edition, John Wiley and Sons, pp. 697.

Hossain, M.A. and Bhuiyan, A.S. (2007). Study of water quality in fish pond under the red soil zone of Northern Bangladesh. Journal of Subtropical Agricultural Research and Development, 5(5): 347-351. 
Hossain, M.A., Mondol, R.C., Biswas, N.R. and Rabbani, M.G. (2010). Production and economics of fish farming in irrigated rice field ecosystem in drought prone barind area of Rajshahi, Bangladesh. Bangladesh Journal of Progressive Science \& Technology, 8(2): 239-242.

Jewel, M.A.S., Affan, A. and Khan, S. (2003). Fish mortality due to cyanobacterial bloom in an aquaculture pond in Bangladesh. Pakistan Journal of Biological Science, 6(12): 10461050, http://www. doi.org/10.3923/pjbs.2003.1046.1050

Jewel, M.A.S., Rahman, M.M. and Sarkar, M.A. (2006). Effects of environmental parameters on the cyanobacterial bloom in a lake of Bangladesh. Bangladesh Journal of Progressive Science \& Technology, 4(2): 159-164.

Li, Di., Wu, N., Tang, S., Su, G., Li, X., Zhang, Y., Wang, G., Zhang, J., Liu, H., Hecker, M., Giesy, J.P. and Yu, H. (2018). Factors associated with blooms of cyanobacteria in a large shallow lake, China. Environmental Science Europe, 30: 27, https://doi.org/10.1186/s12302-018-0152-2.

Nguyen V. and Wood, E.F. (1979). On the morphology of summer algae dynamics in non-stratified lakes. Ecological Modeling, 6: 17-131, https://www.doi.org/10.1016/0304-3800 (79)90030-9

Pabst, M. H., Mathains, J. A. and Barica, J. (1980). Relationship between thermal stability and summer oxygen depletion in a prairie pathole lake. Canadian Journal of Fisheries and Aquatic Science, 37: 1433-1438, http://www.doi.org/10.1139/f80-183

Palikova, M., Navratil, S., Svobodova, Z., Tichy, L., Recek, L. and Pikula, J. (2007). Skin and gonadal tumours in a barbel
(Barbus bar-bus)-a case report. Bulletin of the European Association of Fish Pathologists, 27: 236-238.

Pearl, H. and Tucker, C.S. (2007). Ecology of Blue-Green Algae in Aquaculture Ponds. Journal of the World Aquaculture Society, 26(2): 109-131. https://doi.org/10.1111/j.17497345.1995.tb00235.x.

Rahman, S. and Jewel, M.A.S. (2008). Cyanobacterial bloom and water quality in urban fish ponds. University Journal of Zoology Rajshahi University, 27: 79-84, http://journals.sfu.ca/bd/index.php/UJZRU

Rejmánkováa, E., Komárekb, J., Dixc, M., Komárkovád, J. and Giróne, N. (2011). Cyanobacterial blooms in Lake Atitlan, Guatemala. Limnologica, 41: 296-302. https://doi.org/10.1016/j.limno.2010.12.003

Skulberg, O.M., Carmihael, W.W., Codd, G.A. and Skulberg, R. (1993). Taxonomy of toxic Cyanophyceae (Cyanobacteria). In: Algal Toxins in Seafood and Drinking Water. (ed. I. R. Falcnor), Academic Press Ltd., London, pp. 145-164.

Skulberg, O.M., Codd, G.A. and Carmichael, W.W. (1984). Blue-green algal (Cyanobacteria) Toxins: water Quality and health problem in Europe, AMB, 10(B): 244-247.

Stirling H.P. (1985). Chemical and Biological Methods of Water Analysis for Aquaculturists. Institute of Aquaculture, Scotland: University of Stirling, pp. 119.

Svircev, Z., Lujic, J., Marinovic, Z., Drobac, D., Tokodin, N., Stojiljkovic, B. and Meriluoto, J. (2015). Toxicopathology induced by microcystins and nodularin: a histopathological review. Journal of Environmental Science and Health, 33 (2): 125-167, https://doi.org/10.1080/10590501.2015.1003000 